\title{
Spikelet Fertility Restoration Studies for Identification of Restorers and Maintainers in Rice (Oryza sativa L.)
}

\author{
Ch. Ramesh*, Ch. Damodar Raju, Ch. Surender Raju and N. Rama Gopala Varma \\ Department of Genetics and Plant Breeding, College of Agriculture (PJTSAU), \\ Rajendranagar, Hyderabad - 500 030, Telangana, India \\ *Corresponding author
}

\section{A B S T R A C T}

\section{Keywords}

Oryza sativa, CMS

lines, Restorer,

Spikelet fertility

and Test crosses

Article Info

Accepted:

10 February 2018

Available Online:

10 March 2018
A study was conducted on fertility restoration of 24 Rajendra nagar genotypes to identify the restorers, partial restorers, partial maintainers and maintainers. Twenty four genotypes were test crossed with IR 58025A during rabi 2014-15 at Rice Research Centre, ARI, Rajendra nagar. Out of 24 genotypes 8 were identified as restorers, 10 were identified as partial restorers and 6 genotypes were identified as partial maintainers. None of them were identified as maintainers.

\section{Introduction}

Rice (Oryza sativa L.) is the most important staple food crop for more than 60 percent of the global population and most important crop in Asia. Rice (Oryza sativa L.) is a staple food for over 3 billion people (Cantral and Reeves, 2002).

In many countries, rice accounts for more than 70 percent of human caloric intake. In India rice cultivation area is 44 million hectares and production is 106 million tones where as China produces 144 million tonnes from 30.6 million hectares. In China the rice production is high due to high adoption of hybrid rice where as India the hybrid rice adoption is about 2.5 million hectares (RICESTAT 2014). In hybrid rice seed production three-line system and two-line systems are used. Mostly three line or CGMS (Cytoplasmic Genic Male sterility) system will be followed to eliminate emasculation process.

The combination of a CMS line, maintainer line and restorer line carrying the restorer gene (Rf) to restore the fertility are indispensable for the development of hybrids. The establishment of test cross nursery to identify restorers and maintainers is the first step in three line heterosis breeding (Akhter et al., 2008). 


\section{Materials and Methods}

The CMS line IR 58025A and twenty four rice genotypes of Rajendra nagar were comprised the materials for present study. Those materials were grown in source nursery at Rice Research Centre, Agriculture Research Institute, Rajendra nagar during rabi 2014-15. The pollen parents were planted with a spacing of $20 \mathrm{~cm}$ (row-to-row) x $15 \mathrm{~cm}$ (plantto-plant) in main field.

The CMS lines IR 58025A were tested to assure $100 \%$ pollen sterility before crossing. The panicles of CMS lines were covered with a butter paper at anthesis period to prevent cross pollination. At 10-11 am the pollen was dusted on panicles of IR 58025A CMS lines. So utmost care was taken while test crossing and crossed seeds from the combinations were collected for their evaluation.

\section{Estimation of spikelet fertility}

Estimation was done on three panicles per plant (two selected at random and one from the main culm) from five randomly selected plants for each testcross hybrid at maturity. Spikelet fertility of hybrids was assessed by taking the count of well filled and chaffy spikelets in each panicle.

Spikelet fertility $(\%)=\{$ No. of filled spikelets panicle ${ }^{-1} /$ total number of spikelets panicle $\left.{ }^{-1}\right\} \mathrm{x}$ 100

\section{Classification of pollen parents}

The pollen parents were classified into four categories - Maintainers (M), Partial
Maintainers (PM), Partial Restorer (PR) and Restorer (R) based on their spikelet fertility percentages (Srijan et al., 2015) and presented in the following study.

\section{Results and Discussion}

The test cross establishment is the initial step in fertility restoration studies of three line hybrid rice production. The results showed that out of the attempted test crosses, 24 test crosses were successfully evaluated (Table 1).

It was reported in some cases higher frequency of maintainers (17\%) than that of restorers (11\%) from 65 testcrosses (Akhter $e t$ al., 2008).

The spikelet fertility of hybrids varied from 11.03 to 91.95 . Similar observations have been reported by other researchers (Ali et al., 2014, Krishnalatha and Sharma 2012, Sharma et al., 2012 and Srijan et al., 2015).

In this evaluation 8 genotypes were completely restored, 10 genotypes were partially restored and 6 were identified as partial maintainers. None of them were identified as maintainers. These 8 genotypes (restorers) can contribute for the development of good hybrids by utilizing them as parental lines in hybridization programmes (Table 2).

In this investigation the finding were revealed that fertility restoration reaction was varied with genetic background. These identified restorers were locally adopted genotypes. So, we can use them in production of superior hybrids for local climatic conditions. 
Table.1 Fertility restoration study for identification of restorers and maintainers among 24 lines test crossed with IR 58025A

\begin{tabular}{|c|c|c|c|c|c|c|c|c|}
\hline $\begin{array}{l}\text { S. } \\
\text { No. }\end{array}$ & Hybrids & $\begin{array}{c}\text { Days to } \\
50 \% \\
\text { flowering }\end{array}$ & $\begin{array}{c}\text { No. of filled } \\
\text { grains per } \\
\text { panicle }\end{array}$ & $\begin{array}{c}\text { No. of } \\
\text { unfilled } \\
\text { grains }\end{array}$ & $\begin{array}{l}\text { Total no. } \\
\text { of grains }\end{array}$ & $\begin{array}{c}\text { Spikelet } \\
\text { fertility } \\
\%\end{array}$ & $\begin{array}{c}\text { Grain } \\
\text { yield per } \\
\text { plant }\end{array}$ & $\begin{array}{l}\text { Fertility } \\
\text { reaction }\end{array}$ \\
\hline 1 & IR 58025A $\times$ RNR 21615 & 94 & 300 & 58 & 368 & 81.52 & 12.50 & $\mathrm{R}$ \\
\hline 2 & IR 58025A $\times$ RNR 21604 & 90 & 153 & 17 & 170 & 90.00 & 18.96 & $\mathrm{R}$ \\
\hline 3 & IR 58025A $\times$ RNR 21304 & 89 & 150 & 36 & 186 & 80.60 & 13.83 & $\mathrm{R}$ \\
\hline 4 & IR 58025A $\times$ RNR 21218 & 87 & 183 & 16 & 199 & 91.95 & 24.87 & $\mathrm{R}$ \\
\hline 5 & IR 58025A $\times$ RNR 21301 & 90 & 262 & 43 & 305 & 83.90 & 36.24 & $\mathrm{R}$ \\
\hline 6 & IR $58025 A \times$ RNR 21288 & 86 & 209 & 21 & 230 & 90.08 & 21.76 & $\mathrm{R}$ \\
\hline 7 & IR 58025A $\times$ MTU 1010 & 88 & 190 & 35 & 225 & 84.44 & 18.02 & $\mathrm{R}$ \\
\hline 8 & IR 58025A $\times$ RNR 15048 & 91 & 128 & 25 & 153 & 83.60 & 11.59 & $\mathrm{R}$ \\
\hline 9 & IR 58025A $\times$ RNR 21677 & 93 & 168 & 120 & 288 & 58.33 & 10.74 & PR \\
\hline 10 & IR $58025 A \times$ RNR 21606 & 92 & 273 & 123 & 396 & 68.90 & 17.31 & PR \\
\hline 11 & IR 58025A $\times$ RNR 21230 & 87 & 120 & 225 & 345 & 34.00 & 11.39 & PM \\
\hline 12 & IR 58025A $\times$ RNR 21297 & 89 & 28 & 225 & 253 & 11.03 & 4.07 & PM \\
\hline 13 & IR 58025A $\times$ RNR 21290 & 92 & 95 & 191 & 286 & 33.21 & 10.86 & PM \\
\hline 14 & IR 58025A $\times$ RNR 21232 & 85 & 247 & 80 & 327 & 74.50 & 12.34 & PR \\
\hline 15 & IR 58025A $\times$ RNR 21219 & 92 & 373 & 130 & 503 & 74.15 & $19 . .74$ & PR \\
\hline 16 & IR $58025 A \times$ RNR 21236 & 87 & 123 & 119 & 242 & 50.80 & 11.36 & PR \\
\hline 17 & IR 58025A $\times$ RNR 21222 & 95 & 154 & 80 & 234 & 65.81 & 12.19 & PR \\
\hline 18 & IR 58025A $\times$ RNR 21287 & 88 & 100 & 42 & 142 & 70.42 & 10.30 & PR \\
\hline 19 & IR 58025A $\times$ RNR 21243 & 93 & 116 & 59 & 175 & 66.28 & 10.72 & PR \\
\hline 20 & IR 58025A $\times$ RNR 21295 & 88 & 110 & 210 & 320 & 34.37 & 7.47 & PM \\
\hline 21 & IR 58025A $\times$ RNR 21229 & 84 & 48 & 137 & 185 & 25.94 & 6.89 & PM \\
\hline 22 & IR 58025A $\times$ RNR 19397 & 93 & 74 & 27 & 101 & 73.20 & 9.83 & PR \\
\hline 23 & IR 58025A x RNR 19311 & 90 & 125 & 170 & 295 & 42.37 & 10.43 & PM \\
\hline 24 & IR 58025A $\times$ MTU 1001 & 93 & 121 & 80 & 201 & 60.19 & 9.78 & PR \\
\hline
\end{tabular}

Table.2 Classification of the lines studied based on fertility reaction of test cross hybrids

\begin{tabular}{|c|c|c|c|c|}
\hline S. No. & Class & $\begin{array}{l}\text { Spikelet } \\
\text { fertility } \\
\%\end{array}$ & $\begin{array}{l}\text { No. of } \\
\text { genotypes } \\
\text { identified }\end{array}$ & List of genotypes \\
\hline 1 & Restorers & $>75$ & 8 & $\begin{array}{l}\text { RNR 21615, RNR 21604, RNR 21304, RNR } \\
21218, \text { RNR 21301, RNR 21288, RNR } 15048 \\
\text { and MTU } 1010\end{array}$ \\
\hline 2 & $\begin{array}{l}\text { Partial } \\
\text { Restorers }\end{array}$ & $50-75$ & 10 & $\begin{array}{l}\text { RNR 21677, RNR 21606, RNR 21219, RNR } \\
\text { 21236, RNR 21222, RNR 21287, RNR 21243, } \\
\text { RNR 19397, RNR } 21232 \text { and MTU } 1001\end{array}$ \\
\hline 3 & $\begin{array}{l}\text { Partial } \\
\text { Maintainers }\end{array}$ & $0.1-50$ & 6 & $\begin{array}{l}\text { RNR 21230, RNR 21297, RNR } 21290, \text { RNR } \\
\text { 21295, RNR } 21229 \text { and RNR } 19311\end{array}$ \\
\hline 4 & Maintainers & 0 & 0 & Nil \\
\hline
\end{tabular}

\section{References}

Akhter M, Zahid M A, Sabar M and Ahmad M. 2008.Identification of restorers and maintainers for the development of rice hybrids. Journal of Animal and Plant Science 18(1): 39-41.

Ali, M., Hossain, M. A., Hasan, M.J and Kabir, M. E. 2014. Identification of maintainer and restorer lines in local 
aromatic rice (Oryza sativa). Bangladesh J. Agril. Res. 39(1): 1-12.

Cantral R.P and Reeves, T.G (2002). The cereal of the world's poor takes centre stage. Science 296:53.

Krishnalatha S and Sharma D. 2012. Identification of maintainers and restorers for WA and Kalinga sources of CMS lines in rice (Oryza sativa L.). Electronic Journal of Plant Breeding 3(4): 949-951

Sharma S K, Singh S K, Nandan R and Kumar M. 2012. Identification of restorers and maintainers for CMS lines of rice (Oryza sativa L.). Indian Journal of Plant Genetic Resource 25(2): 186188.

Srijan, A., Sudheer Kumar, S., Damodar Raju, Ch and Jagadeeshwar, R. 2015. Pollen and Spikelet Fertility Studies for the Identification of Good Restorers and Maintainers in Rice (Oryza sativa L.). Research Journal of Agricultural Sciences. 6(4): 751-753.

\section{How to cite this article:}

Ramesh, Ch., Ch. Damodar Raju, Ch. Surender Raju and Rama Gopala Varma, N. 2018. Spikelet Fertility Restoration Studies for Identification of Restorers and Maintainers in Rice (Oryza sativa L.). Int.J.Curr.Microbiol.App.Sci. 7(03): 942-945. doi: https://doi.org/10.20546/ijcmas.2018.703.111 